\title{
EXTERNAL CORROSION OF PIPE RISER API 5L X52 ON TIDAL ZONE OF OFFSHORE PRODUCTION PLATFORM
}

\author{
Wakhid Yani Khoirudin \\ Program Pascasarjana Teknik Mesin, Departemen Teknik Mesin dan Industri \\ Universitas Gadjah Mada Yogyakarta \\ Email : Wakhidyk@yahoo.co.id
}

\begin{abstract}
External corrosion on mature oil and gas field installation very challenging issues. External corrosion of pipeline riser on tidal zone is the most case for pipeline corrosion [2]. API 5 L X52 is familiar pipeline for offshore oil and gas production facilities. Pipeline riser external corrosion on tidal zone have some consequences, time constrain related tidal cycle, production loss, oil spill impact to company reputation, costly maintenance. This research intended to find out effect of tidal cycle and salt water salinity to the rate and type of corrosion on API $5 l$ X52 pipeline riser. Tidal cycle is modeling by wet and dry coupon on salt water. Corrosion rate measure by weight loss coupon. Corrosion product examine by XRD. Chloride contents and oxygen dissolve combination resulting maximum corrosion rate. Oxygen dissolve is main factor to corrosion on salt water. Maximum oxygen dissolve on salt water concentration $3.5 \% \mathrm{wt}$. On high salinity salt water corrosion rate depend oxygen dissolve [2]. Tidal cycle has impact to corrosion rate. General corrosion type happen on all coupon with corrosion product component $\mathrm{Fe}_{2} \mathrm{O}_{3}, \mathrm{Fe}_{3} \mathrm{O}_{4}$ examined by XRD.
\end{abstract}

Keywords : offshore, tidal, corrosion, oxygen, dissolve.

\section{Pendahuluan}

Salah satu tantangan pada lapangan migas lepas pantai adalah facilities integrity berkaitan dengan korosi. Korosi pada struktur dan peralatan produksi. Korosi pada pipa penyalur produksi terjadi dari internal maupun eksternal. Internal korosi disebabkan oleh fluida produksi yang umumnya karena adanya $\mathrm{H}_{2} \mathrm{~S}, \mathrm{CO}_{2}$ dan korosi erosi oleh pasir yang terproduksi. Korosi eksternal terjadi karena dilingkungan air laut yang korosif.. Untuk pipa penyalur antar anjungan korosi paling banyak terjadi pada riser pada daaerah pasang surut (tidal zone) dikarenakan terjadinya korosi pada bagian luar pipa [1]. Pipa penyalur dengan berbahan API 5L X52 banyak dipakai untuk lapangan migas di lepas pantai. Pada lapangan yang sudah beroperasi lebih dari 25 tahun banyak mengakami korosi khusunya korosi bagian luar pada riser pipa pada daerah pasag surut (tidal zone). Perawatan dan perbaikan terhadap korosi pada daerah pasang suruh mempunyai tantangan tersendiri antara lain:

a. Waktu pasang surut yang relative pendek serta kondisi cuaca yang tidak menentu.

b. Kerugian produksi yang cukup besar.

c. Reputasi perusahaan dan biaya penanganan pencemaran yang besar.

d. Biaya perawatan dan perbaikan karena korosi yang relative mahal

Penelitian ini dilakukan untuk mengetahui pengaruh siklus pasang surut terhadap sifat dan laju korosi yang terjadi pada pipa berbahan API 5L X52. Mengetahui pengaruh kadar garam $(\mathrm{NaCl})$ terhadap laju korosi dan sifat korosi pada bahan API 5L X52. 

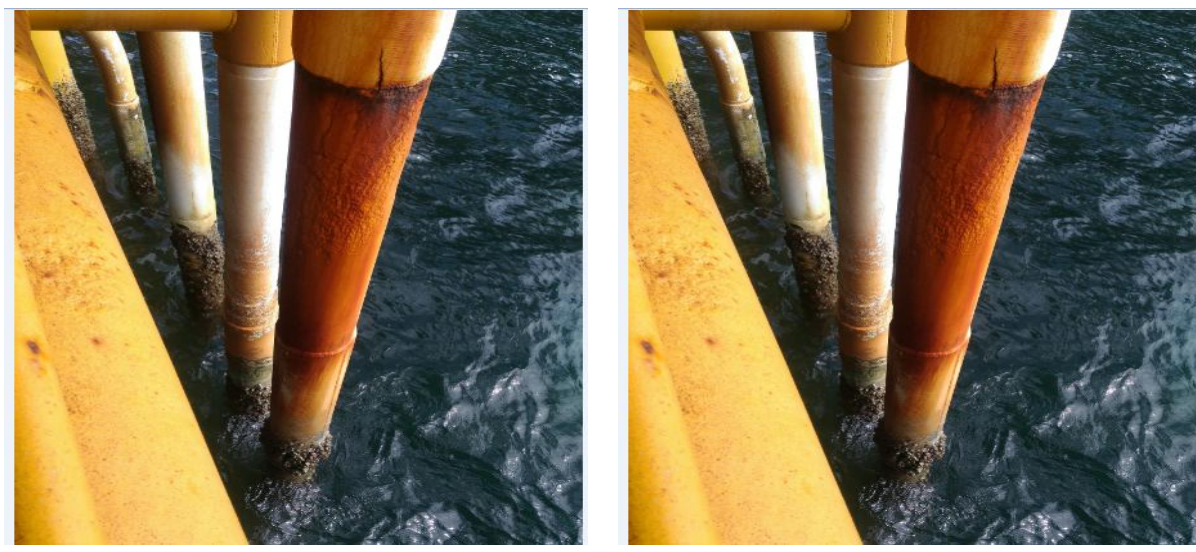

Error! Reference source not found. Riser pipa anjungan lepas pantai

(Sumber koleksi foto Wakhid Yani K)

Pipa penyalur adalah alat transportasi produksi migas yang paling aman dan handal (reliable) untuk menyalurkan cairan dan gas [20]. Bahan yang paling umum dipakai adalah baja karbon. Baja karbon merupakan paduan logam dengan unsur utama besi (Fe) dan karbon (C). Pemilihan bahan pipa penyalur dari baja karbon mempunyai beberapa alasan antara lain memiliki sifat mekanis yang cukup baik, berbiaya rendah, dan ketersediaan yang luas disamping juga ketahanan korosinya yang relatif rendah. Bahan pipa penyalur bawah laut dipilih berdasarkan kriteria biaya, ketahanan terhadap pengaruh korosi, berat yang dibutuhkan, dan kemampuan untuk dilakukan pengelasan (weldability) [4]. Di lapangan pipa bawah laut yang umum digunakan adalah jenis API 5L X52. Evaluasi korosi pada bahan API 5L X52 pada media berkadar Chlorine tinggi (produce water) yang disirkulasi diteliti oleh Likhanoca dkk. [13]. Dari Analisa XPS ion Chloride dan molekul air yang pertama

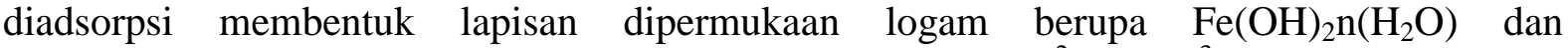
$\mathrm{Fe}(\mathrm{OH}) \mathrm{Cl}\left(\mathrm{H}_{2} \mathrm{O}\right)$. Selanjutnya terjadi proses oksidasi dari $\mathrm{Fe}^{2+}$ to $\mathrm{Fe}^{3+}$. Sifat korosi yang terjadi dipengaruhi oleh kondisi temperature dan lamanya waktu paparan. Sifat permukaan logam berubah dari aktif menjadi passive karena tertutup oleh produk korosi. Korosi yang terjadi berupa general dan local corrosion. General corrosion karena air dan local corrosion karena konsentrasi Chlorine yang tinggi. Lapisan corrosion product tidak compact sehingga memungkinkan ion terdifusi sampai ke logam. Pegaruh thermal and mechanical treatment X52 terhadap ketahanan korosi dalam larutan 3.5\% NaCl diteliti oleh Amaranath, dkk. [1]. Bahwa setelah 20 hari dalam larutan 3.5\% NaCl spesimen X52 yang di quenching dan tempering mempunyai corrosion rate yang minimum dan $10 \%$ cold roll mempunyai laju korosi tertinggi dibandingkan perlakuan panas dan mekanis yang lain. Tingkat kekerasan dan strength yang lebih tinggi berperan dalam ketahanan terhadap erosion-corrosion. Perbandingan korosi yang terjadi pada pipa penyalur baja karbon API 5L X65 untuk daerah pasang surut dibandingkan dengan yang tercelup terus menerus oleh Jianxing dkk, [9]. Hasil penelitian menunjukan untuk daerah pasang surut terjadi pitting corrosion dengan 2 layer korosi porous pada bagian luar dan compact pada bagian dalam. Dengan produk korosi yang utama $\alpha-\mathrm{FeOOH}, \gamma-\mathrm{FeOOH}, \mathrm{Fe}_{3} \mathrm{O}_{4}$, dan $\mathrm{Fe}_{2} \mathrm{O}_{3}$ yang terus meningkat seiring dengan waktu. Untuk yang tercelup terus menerus berupa general corrosion tanpa adanya layering dengan produk korosi yang utama $\gamma-\mathrm{FeOOH}$ and $\mathrm{Fe}_{3} \mathrm{O}_{4}$.

\section{Metodologi Penelitian}

Bahan penelitian ptongan pipa API 5L X52 yang diperoleh dari stock pipe yard perusahaan migas di Kalimantan Timur. Untuk memverifikasi bahan uji dilakukan pengujian tarik, komposisi kimia, mikrostruktur dan kekerasan dan dibandingkan dengan spesifikasi bahan pipa API 5L X52 [2]. Pengujian pengaruh kadar $\mathrm{NaCl}$ terhadap laju dan sifat korosi 
dilakukan dengan merendam specimen ke dalam larutan $\mathrm{NaCl}$ dengan konsentrasi 3.5\%, 7\%, $15 \%$ dan $30 \%$. Pengujian pengaruh pasang surut dimodelkan dengan mencelupkan benda uji ke dalam larutan $\mathrm{NaCl} 3.5 \%, 7 \%$ dan 15\% dengan waktu tercelup 24, 16 dan 20 jam. Laju korosi dihitung dari pengurangan berat selama pengujian. Analisa XRD dilakukan untuk mengetahui komposisi corrosion product.

\section{Hasil dan Pembahasan}

Tabel 1. Hasil pengujian efek salinitas

\begin{tabular}{|c|c|c|c|c|c|}
\hline NO & Spesimen & $\begin{array}{c}\text { Kadar } \\
\mathrm{NaCl}\end{array}$ & mpy & Rata-rata & Std Dev \\
\hline 1 & A-1 & $3.50 \%$ & 0.322 & \multirow{3}{*}{0.368} & \multirow{3}{*}{0.045} \\
\hline 2 & A-2 & $3.50 \%$ & 0.413 & & \\
\hline 3 & $A-3$ & $3.50 \%$ & 0.371 & & \\
\hline 4 & B-1 & $7 \%$ & 0.352 & \multirow{3}{*}{0.311} & \multirow{3}{*}{0.036} \\
\hline 5 & B-2 & $7 \%$ & 0.284 & & \\
\hline 6 & B-3 & $7 \%$ & 0.297 & & \\
\hline 7 & C-1 & $15 \%$ & 0.161 & \multirow{3}{*}{0.166} & \multirow{3}{*}{0.057} \\
\hline 8 & $C-2$ & $15 \%$ & 0.113 & & \\
\hline 9 & $C-3$ & $15 \%$ & 0.225 & & \\
\hline 10 & D-1 & $30 \%$ & 0.193 & \multirow{3}{*}{0.139} & \multirow{3}{*}{0.079} \\
\hline 11 & D-2 & $30 \%$ & 0.176 & & \\
\hline 12 & D-3 & $30 \%$ & 0.048 & & \\
\hline
\end{tabular}

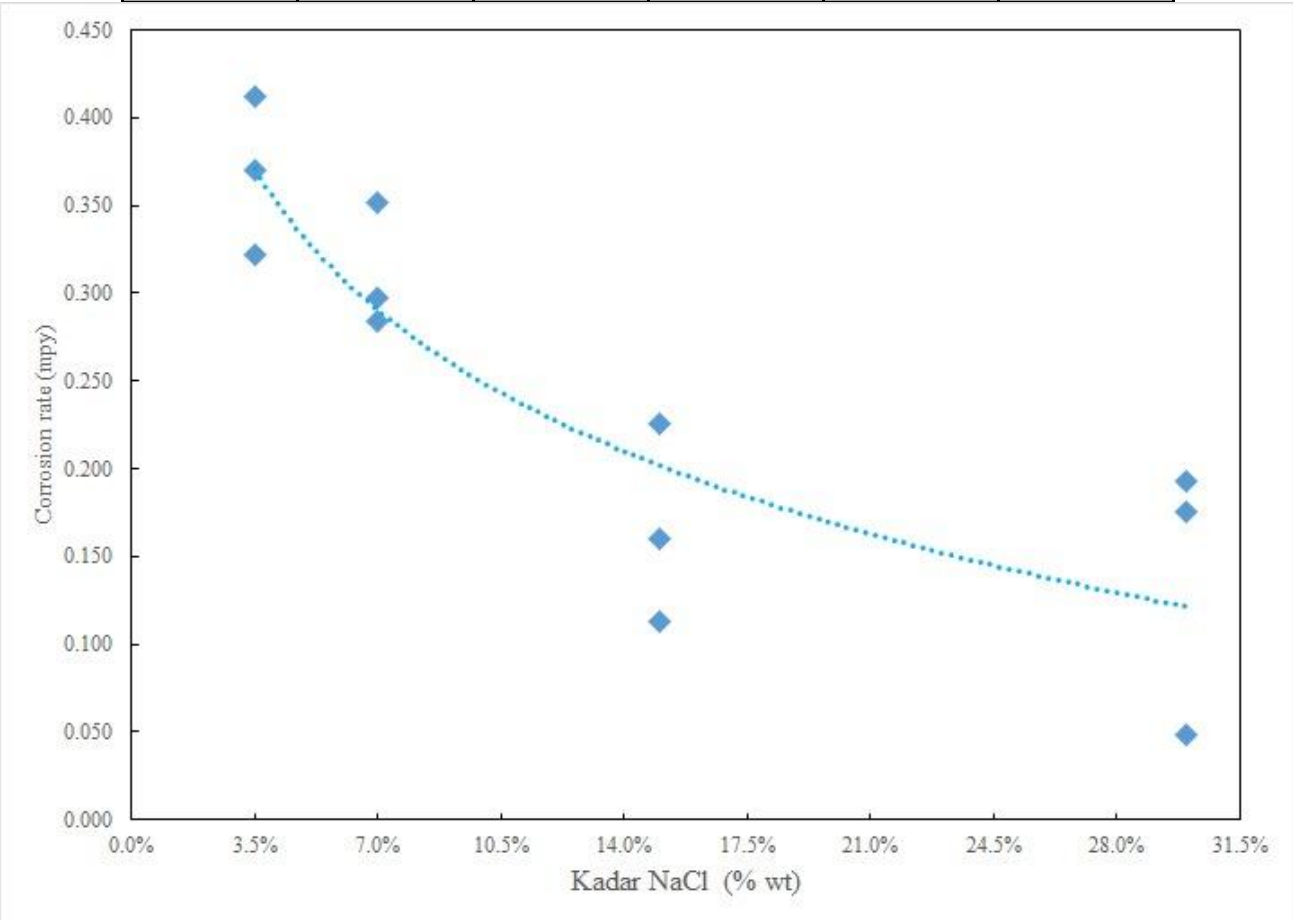

Error! Reference source not found.2 Laju korosi vs kadar $\mathrm{NaCl}$

Data pengujian pengaruh salinitas terhadap laju korosi ditampilkan pada tabel 1. hasil pengujian efek salinitas. dan gambar 2 laju korosi vs kadar $\mathrm{NaCl}$. Laju korosi rata-rata tertinggi terjadi pada konsentrasi larutan $\mathrm{NaCl} 3.5 \%$, sebesar 0.368 mpy, kadar $\mathrm{NaCl} 7 \%$ sebesar 0.311 mpy, kadar $\mathrm{NaCl}$ 15\% 0.166 mpy dan kadar $\mathrm{NaCl} 30 \%$ sebesar 0.139 mpy. Korosi lebih banyak terjadi pada permukaan spesimen yang tidak menempel pada dasar tempat. Bagian spesimen yang yang menempel pada dasar tempat larutan sangat sedikit mengalami korosi. Untuk spesimen dengan larutan $\mathrm{NaCl} 3.5 \%$ dan 7\% korosi terjadi merata 
di permukaan yang tidak menempel pada dasar tempat. Untuk spesimen dengan larutan $\mathrm{NaCl}$ $15 \%$ dan 30\% korosi hanya terjadi di sebagian permukaan, dan terlihat adanya kristal-kristal putih seperti pada gambar 3 Foto korosi efek salinitas. Produk korosi berwarna coklat dan mudah dibersihkan. Korosi yang terjadi adalah general corrosion dan localized corrosion yang di beberapa lokasi secara visual terjadi lebih dalam.
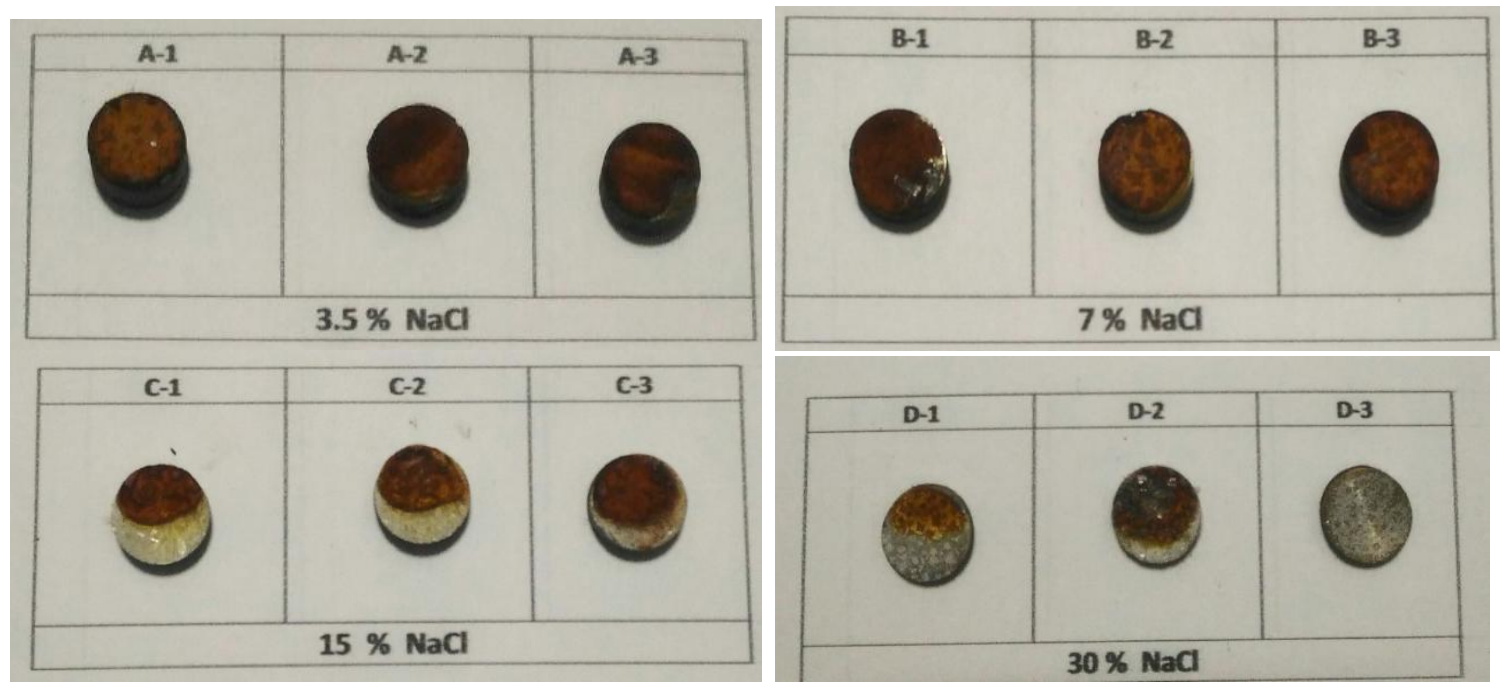

Gambar 3. Foto korosi efek salinitas

Permukaan benda uji yang tidak menempel pada dasar wadah larutan terlihat mengalami korosi lebih banyak dibandingkan yang menempel wadah. Hal ini terjadi karena bagian yang lebih banyak terekspose larutan $\mathrm{NaCl}$ adalah bagian tidak menempel wadah (atas). Pada konsentrasi $\mathrm{NaCl}$ di atas 3.5\% diperoleh kecenderungan laju korosi pada benda uji makin menurun. Gambar korosi yang terjadi pada benda uji untuk konsentrasi 3.5\%, 7\%, $15 \%$ dan $30 \%$ seperti terlihat pada gambar 3. Kelarutan $\mathrm{NaCl}$ dalam air pada suhu ruang maksimal sekitar $360 \mathrm{~g} / \mathrm{L}$ [20]. Kombinasi konsentrasi chloride dan oksigen yang terlarut menghasilkan laju korosi yang maksimum. Konsentrasi kelarutan oksigen tertinggi dicapai pada kadar $\mathrm{NaCl} 3.5 \%$ wt. Kelarutan oksigen adalah faktor utama yang berpengaruh terhadap sifat korosi pada air laut. Pada media air dengan konsetrasi $\mathrm{NaCl}$ yang tinggi laju korosi sebanding dengan kelarutan oksigen. Jika konsentrasi $\mathrm{NaCl}$ dalam air meningkat kelarutan oksigen akan menurun sehinggga laju korosi juga berkurang [5].

Hasil pengujian korosi dengan variasi konsentrasi $\mathrm{NaCl}$ dan siklus waktu pasang surut (pasang tinggi dan rendah) seperti pada tabel 2 dan gambar 4.

Tabel 2. Laju korosi terhadap siklus pasang surut

\begin{tabular}{|c|c|c|c|c|}
\hline $\begin{array}{c}\text { Siklus pasang tinggi } \\
\text { (jam/hari) }\end{array}$ & $\mathbf{3 . 5 \%} \mathbf{~ N a C l}$ & $\begin{array}{c}\mathbf{7 \%} \\
\mathbf{N a C l}\end{array}$ & $\mathbf{1 5 \%} \mathbf{~ N a C l}$ & $\begin{array}{c}\text { Air laut } \\
\text { (aktual) }\end{array}$ \\
\hline 16 & 12.34 & 9.57 & 4.48 & \\
\hline 16 & 14.03 & 9.48 & 5.46 & \\
\hline 16 & 15.38 & 6.54 & 4.16 & \\
\hline 20 & 6.91 & 3.66 & 3.43 & \\
\hline 20 & 6.25 & 3.95 & 2.26 & \\
\hline 20 & 7.21 & 4.11 & 2.93 & \\
\hline 24 & 2.86 & 1.42 & 1.28 & 2.54 \\
\hline 24 & 2.53 & 1.60 & 1.26 & 2.81 \\
\hline 24 & & & & 2.44 \\
\hline
\end{tabular}




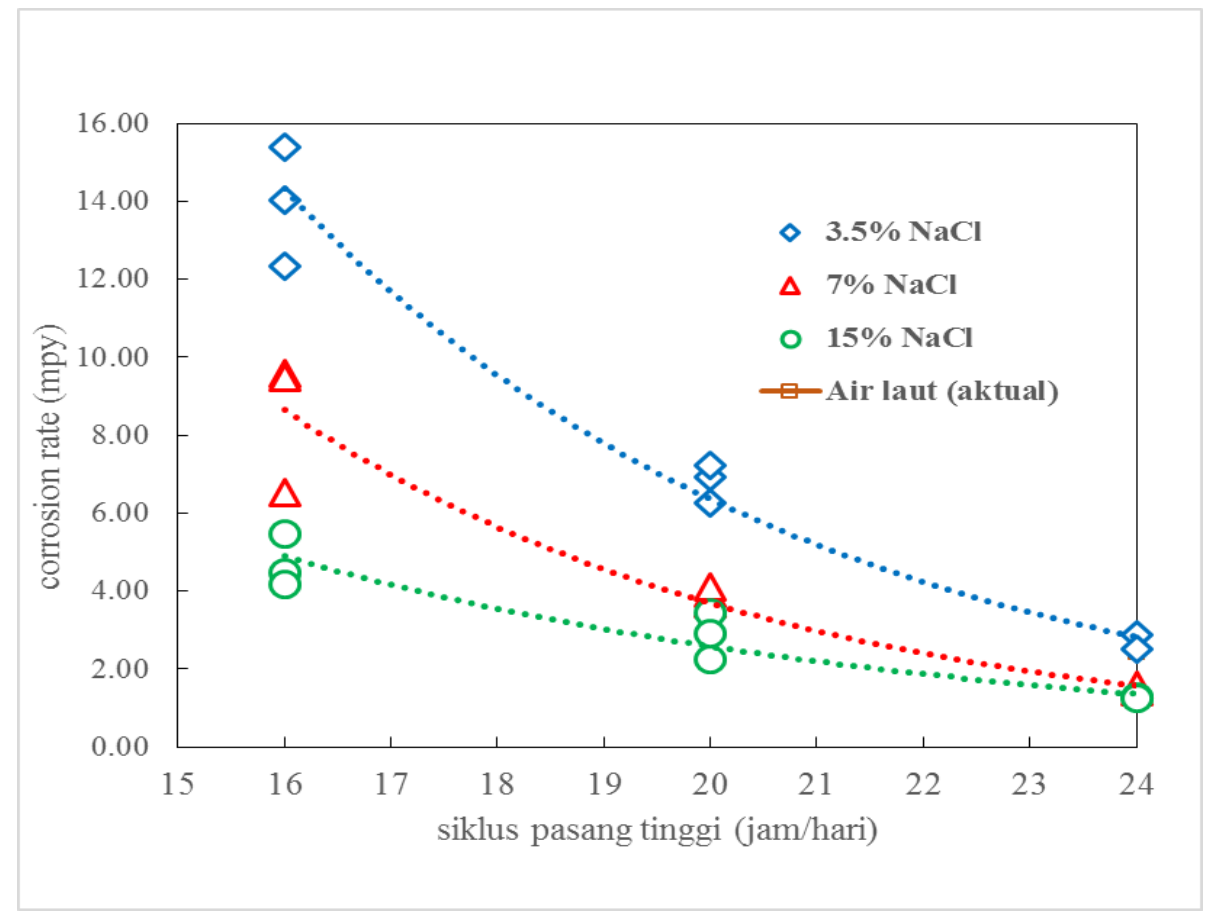

Gambar 4. Laju korosi vs siklus pasang tinggi

Dari pengujian laju korosi pada siklus pasang surut didapatkan umtuk pasang tinggi 24 jam perhari laju korosi mendekati hasil uji korosi pasang tinggi kondisi aktual air laut di lokasi. Laju korosi tertinggi pada konsentrasi 3.5\% dan pasang tinggi selama 16 jam/hari. Untuk siklus pasang surut yang sama untuk konsentrasi di atas $3.5 \%$ laju korosi menurun.

Perubahan siklus pasang naik berpengaruh terhadap laju korosi baik untuk konsentrasi larutan $3.5 \%, 7 \%$ dan $15 \%$. Korosi yang terjadi adalah general corrosion yang relatif merata pada semua permukaan benda uji. Produk korosi berwarna coklat dan mudah terlepas. Dari data pengujian laju korosi diperoleh dengan penurunan waktu siklus pasang tinggi (naiknya waktu pasang rendah) semakin naik laju korosi. Dengan makin naiknya waktu pasang rendah kondisi permukaan spesimen yang lembah akan makin lama terpapar oksigen. Dengan makin lamanya paparan oksigen maka kelarutan oksigen dipermukaan yang lembab akan makin meningkat. Kelarutan oksigen adalah faktor yang dominan mempengaruhi korosi pada lingkungan air laut (garam). Kelarutan oksigen tertinggi pada larutan $\mathrm{NaCl}$ pada konsetrasi $3.5 \%$ wt [2]. Dengan meningkatnya konsetrasi oksigen yang maka laju korosi akan meningkat. Laju korosi rata tertinggi diperoleh untuk konsetrasi $\mathrm{NaCl} 3.5 \%$ dengan siklus pasang tinggi 16 jam atau 8 jam pasang rendah yaitu sebesar 15.378 mpy. Pada konsentrasi $\mathrm{NaCl}$ lebih dari 3.5\% wt, larutan menjadi jenuh kelebihan $\mathrm{NaCl}$ dalam larutan akan mengedap dan menyebabkan kelarutan oksigen dalam larutan berkurang sehingga laju korosi juga menurun.

Persamaan reaksi kimia korosi yang terjadi adalah:

$$
\begin{aligned}
& 2 \mathrm{Fe} \\
& \rightarrow 2 \mathrm{Fe}^{2+}+4 \mathrm{e}^{-} \\
& 4^{\mathrm{e}-}+4 \mathrm{H}^{+}{ }_{(\mathrm{aq})}+\mathrm{O}_{2(\mathrm{~g})} \\
& \rightarrow 2 \mathrm{H}_{2} \mathrm{O} \\
& 2 \mathrm{Fe}+4 \mathrm{H}^{+}{ }_{(\mathrm{aq})}+\mathrm{O}_{2(\mathrm{~g})} \\
& \rightarrow 2 \mathrm{Fe}^{2+}+2 \mathrm{H}_{2} \mathrm{O} \\
& 4 \mathrm{Fe}^{2+}+3 \mathrm{O}_{2}+4 \mathrm{OH}^{-} \\
& \rightarrow 2 \mathrm{Fe}_{2} \mathrm{O}_{3}+4 \mathrm{H}_{2} \mathrm{O} \\
& 3 \mathrm{Fe}_{2} \mathrm{O}_{3}+\mathrm{H}_{2} \\
& \rightarrow 2 \mathrm{~F}_{3} \mathrm{O}_{4}+\mathrm{H}_{2} \mathrm{O}
\end{aligned}
$$


Berdasarkan pada standar laju korosi perusahaan PT AA yang mengacu pada NACE standar. korosi yang terjadi pada benda uji digolongkan pada level moderate hingga severe. Klasifikasi laju korosi yang ditetapkan oleh perusahaan seperti pada tabel 5.5.

Tabel 3 Klasifikasi laju korosi

(Sumber: https://www.cathodic-protection-solutions.com/pipeline-corrosion-case-study/)

\begin{tabular}{|c|c|c|}
\hline \multirow{2}{*}{ Category } & \multicolumn{2}{|c|}{ Average Corrosion Rate } \\
\cline { 2 - 3 } & $\mathrm{mm} / \mathrm{y}$ & $\mathrm{mpy}$ \\
\hline Low & $<0.025$ & $<1.0$ \\
\hline Moderate & $0.025-0.12$ & $1.0-4.9$ \\
\hline High & $0.13-0.25$ & $5.0-10$ \\
\hline Severe & $>0.25$ & $>10$ \\
\hline
\end{tabular}

Dengan kondisi laju korosi yang high hingga severe untuk kondisi pasang tinggi 16 dan 20 jam. Corrosion product yang menempel berfungsi sebagai lapisan pasivasi yang dapat menghambat laju korosi. Dengan kondisi aktual di lapangan perubahan arus dan hempasan gelombang akan bisa melepaskan corrosion product yang menempel. Sehingga dengan terlepasya lapisan pasivasi kemungkinan laju korosi akan lebih tinggi lagi. Oleh karena itu secara operasional di lapangan diperlukan inspeksi dan perawatan yang lebih baik lagi untuk menghindarkan gangguan operasi yaitu terjadinya kebocoran riser pipa yang disebabkan laju korosi yang cukup tinggi.

Pengujian kekerasan yang digunakan adalah Vickers (HVN). Pengujian kekerasan dilakukan pada spesimen yang tidak dan yang terekspose larutan $\mathrm{NaCl}$. Pada spesimen yang tidak terekspose mempunyai nilai kekerasan rata-rata 259.130 HVN. Pada spesimen yang terekspose larutan $\mathrm{NaCl}$ pengujian kekerasan dilakukan pada permukaan potongan melintang. Pada sisi yang dekat daerah terkorosi memberikan hasil nilai kekerasan yang lebih rendah daripada yang lebih jauh dari area yang terkorosi. Nilai kekerasan (HVN) untuk spesimen yag terekspose larutan $\mathrm{NaCl} 3.5 \%$ dan $7 \%$ dengan siklus pasang naik 16 dan 20 jam nilai rata-rata $\mathrm{HVN}$ lebih rendah dibanding spesimen yang tidak terekspose larutan $\mathrm{NaCl}$. Makin naik konsentrasi larutan $\mathrm{NaCl}$ makin menurun kekerasan. Hasil pengujian kekerasan seperti pada tabel 4.

Tabel 4. Hasil uji kekerasan

\begin{tabular}{|c|c|c|c|c|c|}
\hline HVN & Awal & $\begin{array}{c}\mathbf{3 . 5 \%} \\
\mathbf{1 6} \text { jam }\end{array}$ & $\begin{array}{c}\mathbf{3 . 5 \%} \\
\mathbf{2 0} \text { jam }\end{array}$ & $\begin{array}{c}\mathbf{7} \text { \% } \\
\mathbf{1 6} \text { jam }\end{array}$ & $\begin{array}{c}\mathbf{7 \%} \\
\mathbf{2 0} \text { jam }\end{array}$ \\
\hline 1 & 267.231 & 170.248 & 155.766 & 158.510 & 153.532 \\
\hline 2 & 263.680 & 213.042 & 206.000 & 209.477 & 206.000 \\
\hline 3 & 246.943 & 224.302 & 224.302 & 220.452 & 216.700 \\
\hline 4 & 270.855 & 216.700 & 209.477 & 209.477 & 213.042 \\
\hline 5 & 246.943 & 192.924 & 189.850 & 186.848 & 196.074 \\
\hline Rata-rata & 259.130 & 203.443 & 197.079 & 196.953 & 197.070 \\
\hline STDEV & 11.411 & 21.884 & 26.141 & 24.728 & 25.577 \\
\hline
\end{tabular}




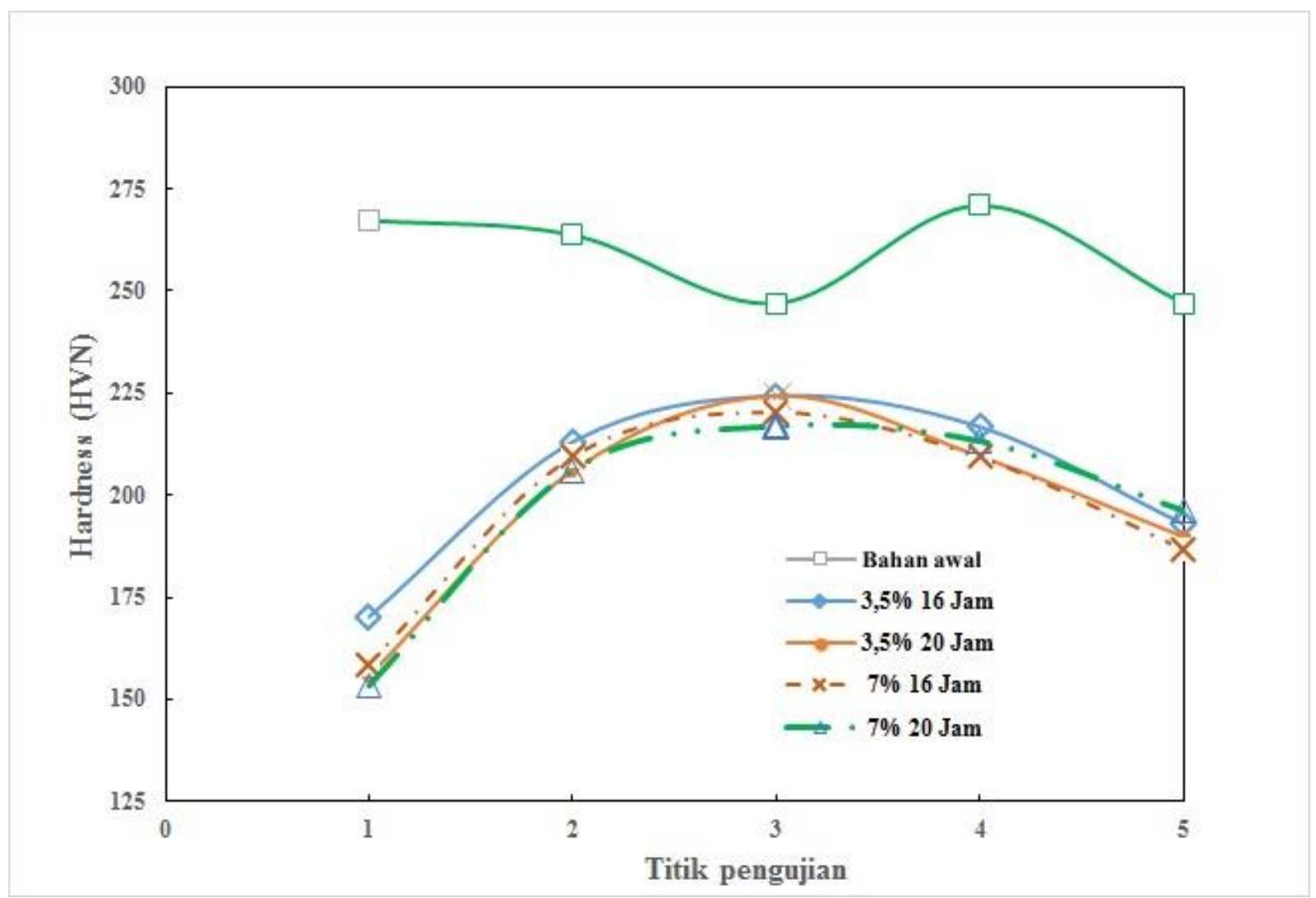

Gambar 4. Hasil uji kekerasan

Makin tinggi konsentrasi larutan $\mathrm{NaCl}$ makin makin tinggi jumlah ion chlorine $\left(\mathrm{Cl}^{-}\right)$ dalam larutan. Spesimen yang terendam dalam larutan yang mengandung ion $\mathrm{Cl}^{-}$yang tinggi dalam waktu yang lama akan makin banyak terekspose ion $\mathrm{Cl}^{-}$, yang akan meningkatkan kerusakan lapisan pasivasi sehingga terjadi korosi. Jika spesimen mengalami korosi maka kekuatan mekanisnya akan menurun dan kekrasannya akan menurun juga [21].

Dari hasil analisa XRD peak yang sesuai dengan corrosion product adalah, $\mathrm{Fe}_{2} \mathrm{O}_{3}$, $\mathrm{Fe}_{3} \mathrm{O}_{4}$. Hasil analisa ini sesuai dengan persamaan reaksi (6) dimana hasil akhir reaksi corrosion product yang didapatkan adalah $\mathrm{Fe}_{2} \mathrm{O}_{3}$ (ferro III oxide), Magnetite $\left(\mathrm{Fe}_{3} \mathrm{O}_{4}\right)$. Untuk spesimen dengan konsentrasi $\mathrm{NaCl} 7 \%$ dan siklus pasang tinggi 16 jam dari analisa XRD diperoleh senyawa $\mathrm{NaOH}$. Senyawa $\mathrm{NaOH}$ tersebut adalah impurities hasil reaksi larutan padat $\mathrm{NaCl}$ dalam air. 


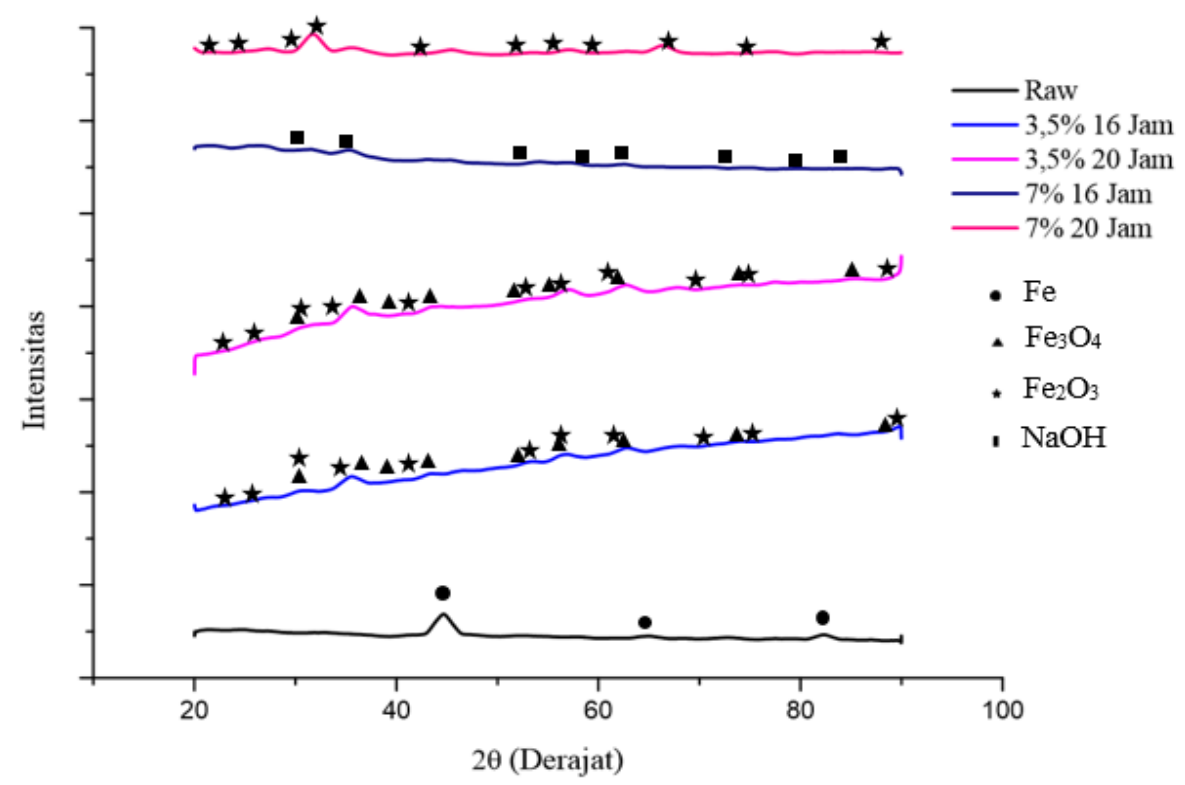

\section{Kesimpulan}

a. Kelarutan oksigen adalah faktor yang dominan mempengaruhi korosi dalam larutan garam $\mathrm{NaCl}$. Kelarutan oksigen tertinggi pada larutan $\mathrm{NaCl}$ dengan konsentrasi 3.5\% wt. Makin tinggi konsentrasi $\mathrm{NaCl}$ makin turun kelarutan oksigen.

b. Siklus pasang surut berpengaruh terhadap laju korosi, makin pendek waktu pasang naik perhari laju korosi makin meningkat. Laju korosi tertinggi terjadi pada larutan $\mathrm{NaCl}$ $3.5 \%$ wt. Pada pasang naaik 16 jam/hari dan korosi yang terjadi masuk kategori high hingga severe.

\section{Ucapan Terimakasih}

Kepada:

1. Bapak Muslim Mahardika, S.T., M.Eng., Ph.D.

2. Bapak Dr. Suyitno, S.T., M.Sc.

3. Bapak Sunhaji

4. Bapak Ikhsan Budi S.T.M Eng.

\section{Daftar Pustaka}

[1] Upadhyay, S. N., \& Namboodhiri, T. K. G. (2003). Effect of thermal and mechanical treatments on corrosion of API X-52 grade line pipe steel in flowing $3.5 \% \mathrm{NaCl}$ solution.

[2] Amira N. B. M. R (2015). A Study On The Performance of Splash Zone Coating System, Universiti Teknologi PETRONAS, Malaysia

[3] API. (2013). Specification for Line Pipe. In API Specification 5L.

[4] Bai Y. (2001). Pipelines and Risers, Elsevier Ocean Engineering Book Series Volume 3

[5] Bhandari, J., Khan, F., Abbassi, R., Garaniya, V., \& Ojeda, R. (2015). Modelling of pitting corrosion in marine and offshore steel structures-A technical review. Journal of Loss Prevention in the Process Industries, 37, 39-62.

[6] Cervantes-Tobón, A., Godínez-Salcedo, J. G., Gonzalez-Velazquez, J. L., \& Díaz-Cruz, M. (2014). Corrosion rates of API 5L X-52 and X-65 steels in synthetic brines and brines with H2S as a function of rate in a rotating cylinder electrode. International Journal of Electrochemical Science, 9(5), 2454-2469.

[7] Callister W.D. Jr. and Rethwisch D.G, Materials Sciences and Engineering An Introduction $9^{\text {th }}$ Edition, John Wiley \& Sons. 
[8] Askeland, D. R., Fulay, P. P., \& Wright, W. J. (2011). The science and engineering of materials. Nelson Education.

[9] Yu, J., Wang, H., Yu, Y., Luo, Z., Liu, W., \& Wang, C. (2018). Corrosion behavior of X65 pipeline steel: Comparison of wet-Dry cycle and full immersion. Corrosion Science, 133, 276-287.

[10] LINS, Vanessa de Freitas Cunha; FERREIRA, Mitchel Leonard Magalhães; SALIBA, Patrícia Alves. Corrosion resistance of API X52 carbon steel in soil environment. Journal of Materials Research and Technology, 2012, 1.3: 161-166.

[11] Liang, M., Melchers, R., \& Chaves, I. (2018). Corrosion and pitting of 6060 series aluminium after 2 years exposure in seawater splash, tidal and immersion zones. Corrosion Science, 140, 286-296.

[12] Corrales-Luna, M., Olivares-Xometl, O., Likhanova, N. V., Ramírez, R. E. H., Lijanova, I. V., Arellanes-Lozada, P., \& Estrada, E. A. (2017). Influence of the immersion time and temperature on the corrosion of API X52 steel in an aqueous salt medium. International Journal of Electrochemical Science, 12(7), 6729-6741.

[13] Likhanova, N. V., Nava, N., Olivares-Xometl, O., Domínguez-Aguilar, M. A., Arellanes-Lozada, P., Lijanova, I. V., ... \& Lartundo-Rojas, L. (2018). Corrosion evaluation of pipeline steel API 5L X52 in partially deaerated produced water with high chloride content. Int. J. Electrochem. Sci, 13, 7949-7967.

[14] Malau V., (2018), Korosi, Mechanical and Industrial Engineering Dept. Faculty of Engineering, Gadjah Mada University

[15] Melchers, R. E. (1994). Pitting corrosion in marine environments: a review. Department of Civil Engineering and Surveying, University of Newcastle.

[16] Nontji A. (2007). Laut Nusantara. Jakarta: Djambatan.

[17] Adedipe, O., Brennan, F., \& Kolios, A. (2016). Review of corrosion fatigue in offshore structures: Present status and challenges in the offshore wind sector. Renewable and Sustainable Energy Reviews, 61, 141-154.

[18] Pavuluri, S. (2014). Kinetic approach for modeling salt precipitation in porous-media. GRIN Verlag.

[19] Rihan, R. O. (2013). Electrochemical corrosion behavior of X52 and X60 steels in carbon dioxide containing saltwater solution. Materials Research, 16(1), 227-236.

[20] Zaferani, S. H. (2015). Failure Analysis of Corrosion Case Histories.

[21] Salleh, M. M., Al Bakri, A. M., Alida, A., \& Kamarudin, H. (2013). Effects of Seawater (Salt Water) to Aisi 304 Mechanical Properties. Australian Journal of Basic and Applied Sciences, 7(7), 545-554.

[22] Wildan, M.W. (2018).,Pengujian dan Karakterisasi Material (PKM), Department of Mechanical and Industrial Engineering. Gadjah Mada University

[23] Yulianda F.(2009). Pengantar Lingkungan Laut. Institut Pertanian Bogor 
Wakhid Yani Khoirudin 